\title{
Intensive Care Unit team perception of palliative care: the discourse of the collective subject*
}

\author{
A equipe da Unidade de Terapia Intensiva frente ao cuidado \\ paliativo: discurso do sujeito coletivo \\ El equipo de la Unidad de Cuidados Intensivos ante el \\ cuidado paliativo: discurso del sujeto colectivo
}

Juliana El Hage Meyer de Barros Gulini' ${ }^{1}$ Eliane Regina Pereira do Nascimento ${ }^{2}$, Rachel Duarte Moritz ${ }^{2}$, Luciana Martins da Rosa ${ }^{2}$, Natyele Rippel Silveira ${ }^{2}$, Mara Ambrosina de Oliveira Vargas ${ }^{2}$

How to cite this article:

Gulini JEHMB, Nascimento ERP, Moritz RD, Rosa LM, Silveira NR, Vargas MAO. Intensive care unit team perception of palliative care: the discourse of the collective subject. Rev Esc Enferm USP. 2017;51:e03221. DOI: http://dx.doi.org/10.1590/S1980-220X2016041703221

*Extracted from the thesis "Protocolo interdisciplinar para o controle da dor, dispneia e hipersecreção em pacientes sob cuidado paliativo na Unidade de Terapia Intensiva”, Programa de Pós-Graduação em Enfermagem, Universidade Federal de Santa Catarina, 2016.

${ }^{1}$ Universidade Federal de Santa Catarina, Programa de Pós-Graduação em

Enfermagem Florianópolis, SC, Brazil.

${ }^{2}$ Universidade Federal de Santa Catarina, Departamento de Enfermagem,

Florianópolis, SC, Brazil.
Corresponding author:

Juliana El Hage Meyer de Barros Gulini

Rua Prof ${ }^{a}$. Maria Flora Pausewang, $\mathrm{s} / \mathrm{n}^{\circ}$

Campus Universitário - Trindade

CEP 88036-800 - Florianópolis, SC, Brazil

julianagulini75@gmail.com

\begin{abstract}
Objective: To learn the perception of health professionals in an Intensive Care Unit towards palliative care. Method: This was a descriptive and qualitative study based on the converging care approach conducted at an intensive care unit in the South of Brazil. Semistructured interviews were used to investigate the understanding of the professionals about palliative care in this unit. The data were organized and analyzed using the discourse of the collective subject method with the help of Qualiquantisoft ${ }^{\circledR}$ software. Results: Participants included 37 professionals (12 nurses, 11nursing technicians, 5 physical therapists and 9 doctors). The key ideas extracted from the interviews were: care in the end stage of life that avoids futile measures; comfort care; lack of standardized care and lack of team training. Conclusion: The professionals perceived palliative care as appropriate in the last stages of life, with no need for futile treatment or as comfort measures. However, they are aware of the lack of standardization and lack of capacity building in this area, which leads them to conceive palliative care as terminal care, and measures are recommended to break with this stigma.
\end{abstract}

DESCRIPTORS

Palliative Care; Intensive Care Units. Nursing, Team; Patient Care Team. 


\section{INTRODUCTION}

For decades, intensive care professionals have focused on increasing short-term survival. More recently, intensive care has expanded to improve long-term survival results in critical illnesses and improve the quality of life of patients who are subject to premature death ${ }^{(1)}$.

Palliative care (PC) is based on reducing distressing symptoms, establishing clear and sensitive communication, aligning treatment with patient preferences, and providing family support ${ }^{(2)}$. This modality of care aims to improve quality of life of patients and families facing problems associated with life-threatening illnesses ${ }^{(3)}$.

Internationally, research in the area has contributed to disseminating and implementing PC, playing an essential role in achieving its principles, philosophy and objectives ${ }^{(4)}$. Thus, PC has been gaining the spotlight in current discussions among health professionals in caring for patients with incurable chronic diseases, and more recently, acute patients, such as those in Intensive Care Units (ICUs) ${ }^{(5)}$.

Due to the wide range of therapeutic needs presented by PC patients, authors defend that this approach should involve multiprofessional teams, including physicians, nurses, physical therapists, psychologists, psychiatrists, nutritionists, speech therapists, social workers, pharmacists, spiritual counselors and priests, to make care more comprehensive and provide critically ill patients with every possible care option, thus ensuring better quality of life ${ }^{(6-7)}$.

Therefore, $\mathrm{PC}$ requires a specialized multiprofessional team to provide the terminally ill patient with care that addresses all of their dimensions, ensuring wellbeing and respecting human dignity ${ }^{(8)}$.

Palliative care should be integrated into the ICU environment and establish itself as a care philosophy that seeks to provide relief from pain and other symptoms, and spiritual and psychosocial support regarding end of life and bereavement ${ }^{(3,8)}$.

The search for a framework to better organize $\mathrm{PC}$ in a critical care unit led the authors to conduct a study to learn the perception of palliative care held by ICU health professionals.

\section{METHOD}

This was a qualitative study that used the convergent care research framework, which consists of five phases or procedures: conception, instrumentation, detailed phase, analysis and interpretation of results ${ }^{(9)}$. The conception phase includes establishing the object of study, objectives and theoretical framework. Next, during instrumentation, data collection procedures are described, including the study setting, participants, and data collection methodologies. In the detailed phase, the researchers describe how the data will be collected. The last phase defines how the data will be analyzed or interpreted and addresses concerns related to ethical rigor.

The study was developed in a 12 -bed ICU in the University Hospital of the Universidade Federal de Santa Catarina (UFSC), Brazil. This unit receives mainly individuals with respiratory complications and postoperative patients. Ninety-eight professionals work in the unit. This research proposal was approved by the institution's research ethics committee, under ruling no. 959.555/2015 and CAAE 36643714.1.0000.0118, abiding by ethical principles ${ }^{(10)}$.

Inclusion criteria consisted of professionals working at the ICU for a minimum of six months, time needed for professionals to gain experience with caring for PC patients. Professionals who were on leave or vacation from work during data collection were excluded.

The sample included physicians, nurses, nursing technicians, and physical therapists. These participants were chosen because the study focused on PC patients with pain, dyspnea, and hypersecretion, and in the ICU, these professional categories are directly involved in relieving such symptoms.

Data collection took place between March and May, 2015, using semi-structured interviews. The script covered participant characteristics, such as age, gender, highest level of education, and two guiding questions were asked: What do you understand about palliative care? and How do you perceive palliative care in the ICU? The interviews were individual, recorded with the participant's consent, and later transcribed, lasting an average of 30 minutes. Participants signed a free and informed consent form before participating. Furthermore, anonymity was ensured by identifying each interviewee with the letter I followed by numbers indicating the order of the interview, for example: I1, I2... Data were gathered until data saturation, obtaining sufficient material to learn about the object of study.

As a method, the discourse of the collective subject (DCS) was used to organize and analyze the data. This method includes four methodological figures: Key Expressions (KE), which reveal the essence of the content of the interviews; Central Ideas (CI), which indicate the meaning or linguistic expression of the analyzed statement and each set of $\mathrm{KE}$ with the same meaning or complementary meaning which will later compose the DCS; Anchoring (AC) which includes the assumptions, principles, hypotheses, and theories that underpin the key expressions, and the DCS, which is a synthesis discourse written in the first person, with $\mathrm{KE}$ that have similar or complementary $\mathrm{CI}$ and $\mathrm{AC}^{(11)}$.

The interviews were methodologically processed using Qualiquantisoft ${ }^{\circledR}$ software. This tool performs qualitative analysis via DCS and quantitative analysis through the frequency of shared discourse among individuals, i.e., discourses with the same CI. Therefore, after the interviews were transcribed and typed, the software aided in the operationalization of categories, creation of discourse, and the production of quantitative reports. The latter presents the percentage of individuals who contributed with their key expressions relative to the central ideas.

\section{RESULTS}

Of the 37 professionals who participated in the study, 12 were nurses, 11 were nursing technicians, 5 were physical therapists, and 9 were physicians. Of these, 32 (86.5\%) were women and $5(13.5 \%)$ were men. Mean participant age was 37 years, and the mean age among women was 36 and among men, 45 . In terms of highest level of education, 5 
(13.5\%) of those interviewed had complete high school education; 11 (29.7\%), complete higher education; 17 (45.9\%) had a Master's degree; and 4 (10.8\%) had a Ph.D., contributing to a qualified sample.

Based on the first question (What do you understand about palliative care?), two DCS emerged from their respective CIs. The quantitative analysis conducted by the software demonstrated that $12(30.77 \%)$ of those interviewed defined it as end-of-life care in which futile treatment is avoided, and 27 (69.23\%) understood it as comfort care. Two of the participants gave answers that contained more than one central idea, resulting in a total of 39 definitions.

\section{Central IdeA A - END-OF-life CARE IN Which fUtile MEASURES ARE AVOIDED}

DCS 1: I think that it consists of care given to patients who are on the brink of death, with no perspective of treatment, when they have no more therapeutic options, incurable. It's when the patient no longer needs more aggressive intervention, for it will not save their lives, only prolong suffering. It includes care given to patients at the final stages of life or that are reaching the end. It's care with the minimum amount of futile interferences, which will only prolong suffering, both for the patient and their family (I6, I8, I11, I14, I15, I16, I21, I24, I25, I26, I34, I36).

\section{Central Idea B - Comfort Care}

DSC 2: I understand that it means providing comfort care to patients who can no longer be cured, who have an irreversible disease, patients who are not progressing even with all the treatment provided, so comfort care is maintained, in pre-death condition. They consist of measures that provide basic comfort and support to patients at the end of life, which do not aim to cure the underlying disease, but treat the symptoms that distress patients, providing the necessary comfort so that they can pass away, relieving their suffering, pain, and slightly improving the quality of life of their remaining days. It means providing them with the best care possible, in order to eliminate whatever is bothering them so that the illness or life itself can follow the most natural course possible. It means trying to meet patients' wishes, like a child, making some exceptions to improve personal satisfaction. It includes procedures to make them comfortable, in a pleasant condition, of wellbeing, which can include medication, massage, conversation, anything that makes them feel better while going through the illness process, and prevent wounds, provide adequate mobilization, prepare patients for the evolution of their disease and family members for the outcome and the evolution of the disease until the moment of death, should it be unavoidable (I1, I2, I3, I4, I5, I7, I9, I10, I12, I13, I14, I17, I18, I19, I20, I22, I23, I26, I27, I28, I29, I30, I31, I33, I37, I35).

Regarding the second question (How do you perceive palliative care in the ICU?), most of the participants, or $30(81.08 \%)$ of those interviewed reported lack of care standardization and seven (18.92\%) perceived insufficient team training.

This question also resulted in two DCS with one CI each.

\section{Central IdeA A - LACK Of CARE standardization}

DCS 3: The problem here is lack of agreement on when such palliative care must be implemented. We need protocols, a uniformed conduct. People have different ways of seeing it. One second it's palliative care, then it's not anymore, there's no one single line of thought, it's not standardized, there is no consensus, one person thinks one way, the other person does something else, the patient should no longer be invested in, but they continue with their treatment, and then shifts change and everything is removed... The patient doesn't die, another shift changes and everything is put back again... So it's a bit confusing for the team, and it ends up creating conflict between the team and even with the family (I2, I3, I5, I6, I7, I8, I11, I12, I14, I15, I16, I17, I18, I19, I20, I21, I22, I23, I25, I26, I27, I28, I29, I30, I31, $\mathrm{I} 32, \mathrm{I} 33, \mathrm{I} 34, \mathrm{I} 36, \mathrm{I} 37)$.

\section{Central IdeA B - Lack of Team training}

DCS 4: Lack of knowledge to understand pre-death symptoms and also preparation to talk with the family throughout the death process. We are not well prepared yet, we have many difficulties. In the ICU, if I want to leave a family member, there's always much concern, because there isn't enough infrastructure to receive families. The team doesn't really understand what palliative care is. What makes a great difference is having professionals who are truly trained in palliative care, specialized in the field, but there is lack of communication, more reading is necessary to understand more about palliative care, what palliative care is, what full and partial palliative care are. We need to involve technical-level professionals a little bit more so that we can improve as a whole and reach the same understanding, we need to invest in training so that everybody understands that they have a common goal. So I think that we need team training, because the team needs to be prepared and committed to palliative care (I1, I4, I9, I10, I13, I24, I35).

\section{DISCUSSION}

Palliative care patients are defined as those whose disease does not respond to curative treatment or is life-threatening $^{(12)}$. The concept of PC is dynamic and has gained new meaning over time, which has resulted in new associated models and concepts, such as pre-terminal care, terminal care and end-of-life care ${ }^{(13)}$.

The first collective discourse shows lack of consensus among health professionals about the stage of life targeted by PC. Twelve participants (30.77\%) understood that PC is the care of patients with incurable diseases, and thus, clearly associated PC with the last stages of life. This demonstrates the limited nature of these professionals' understanding, as $\mathrm{PC}$ can be adopted not only at the end of life, but especially with ICU patients.

The aims of PC include relieving symptoms, establishing effective communication, aligning treatment with patient preferences, supporting family members, and planning for transitions. Considering that PC or terminal care is for patients who are near death, $\mathrm{PC}$ is considered appropriate in the context of any serious illness, regardless of stage 
or prognosis, and ideally should be coupled with restorative curative therapy ${ }^{(14)}$.

Traditionally, PC has been related to advanced illnesses and end-of-life care, which is associated with limited life expectancy ${ }^{(15)}$.

Recognizing the moment in which treatment is considered futile or knowing when a given intervention does not meet the established therapeutic objectives of a specific patient are complex processes. Thus, one of the most difficult decisions to be made by the team in the palliative approach involves defining what measures should be continued and which should be suspended ${ }^{(8)}$.

Regarding comfort care, PC involves several types of measures. Currently, more proactive approaches have been developed to provide PC through educational initiatives among ICU teams, such as tools for bedside communication and symptom management ${ }^{(16)}$.

The current definition of $\mathrm{PC}$ indicates an approach that improves the quality of life of patients and families who face life-threatening diseases, via measures to prevent and relieve suffering, early identification and assessment, and impeccable treatment for pain and other physical, psychosocial and spiritual problems ${ }^{(6)}$.

Furthermore, this definition of PC emphasizes the importance of managing symptoms throughout the entire active phase of a patients' illness, even before the terminal stage. Introducing PC to patients when they are still receiving curative treatment contributes to improving the quality of the care received throughout the course of the disease and, therefore, their quality of life. Although including PC in the initial phase of the disease is still rare, especially in the scenario of this study, it is considered an option for terminal patients, as it encompasses comfort and holistic care for any type of patient, including those receiving curative cancer treatment, with HIV/AIDS, and older adults with chronic illnesses ${ }^{(17)}$.

In ICUs, professionals frequently make decisions about life support treatments. However, with ICU patients, it is difficult to know the exact moment in which palliative care is more indicated than curative care, as these coexist with comfort care. Comfort care is defined as care that considers individual physical aspects, coupled with psychological, social and spiritual aspects. As it is usually heard in the field of intensive care, "to cure sometimes, to relieve often and to comfort always"(18).

Excellent symptom control, ongoing commitment to serving the patient and family, and providing physical, psychological, and spiritual support are the hallmarks of highquality end-of-life care. Such care has been emerging in ICUs and requires the same high-level knowledge and skills as those in all of the other fields involved. Patients who are approaching death in the ICU want symptom relief, their wishes respected, and being surrounded by loved ones. The most important factors of high-quality patient care include trust and confidence in the team's treatment, avoiding life support when there is little hope of significant recovery, honest information about the illness, ongoing care, and endof-life preparation ${ }^{(19)}$.
Additionally, ICU professionals must also address one of the challenges associated with end-of-life care: interdisciplinary collaboration, including differing opinions about the patient's potential for recovery, communication problems within interdisciplinary team, and lack of nursing participation in decision-making processes. Guidelines involving interdisciplinarity can help to clarify, describe and obtain consensus about end-of-life norms in decision-making and care measures, and thus, improve satisfaction with interdisciplinary collaboration and patient care ${ }^{(20)}$.

Health team communication must be enhanced for practices to be standardized. Communication is essential to professionals working with $\mathrm{PC}$, as it improves their access to and approach of the patients' emotional dimension, thus improving patient care ${ }^{(21)}$.

Communication can be hindered in ICUs due to multiple aspects intrinsic to intensive care, among them complexity. Outcomes are always uncertain, a condition that affects decision making and intensifies the stress of all those involved, including patients, family, and health teams. Furthermore, professionals are frequently faced with ethical dilemmas associated with the rise of technology and greater treatment options. All of these elements indicate the challenging nature of communication in the ICU. The main source of conflict in ICUs lies in end-of-life care, due to problems associated with decisions and communication ${ }^{(22)}$.

The absence of care protocols hinders decision making regarding implemented care and what treatments should be continued for PC patients ${ }^{(8)}$.

Another strong point present in the discourse was the perception that in the ICU professionals are not prepared to deal with PC patients, there is lack of knowledge, suitable training, and involvement of all members of the multiprofessional team. Thus, even though it is a place where death is always present, professionals who provide intensive care are not adequately trained or qualified for end-of-life care.

Training aims to provide a multidisciplinary communication approach to families of critical patients, in order to improve communication among professionals and between patients and their families, increase level of personal comfort, and improve transition to comfort care ${ }^{(23)}$.

A similar study conducted with a multiprofessional team regarding palliative care in the hospital context also indicated the need for training care teams to manage the terminality process, as some participants were not prepared to care for this type of patient ${ }^{(24)}$.

Another study demonstrated the resignification of care in a specialized PC unit, in which professionals shifted from illness-centered care to person-centered care and humanizing patient care. The authors present an example of a patient and family who, at the final moments of life, choose not to go to an ICU, showing the need for more than just technology, but more encompassing care that includes the psychoemotional dimensions related to end of life ${ }^{(25)}$.

A possible limitation of this study includes the fact that it was conducted in only one ICU. Thus, this study should be replicated in other ICUs to validate its results and investigate perceptions different from those found in this study. 


\section{CONCLUSION}

Palliative care is a philosophy that still needs to be explored within ICUs and needs to be clarified among professionals. The ICU team in this study perceived PC as appropriate in the final stages of life, which avoids futile treatment measures, and provides comfort care to patients and their family members. The participants also reported the need for improving communication among ICU team professionals to establish more standardized patient care. They referenced the need for training, so as to improve patient care in the end of life, and provide the necessary support to family members.

Insufficient professional education in PC interferes when establishing whether or not a patient should be admitted into the ICU and what care they should receive. In other words, it impacts the definition of what treatments should be implemented despite of a PC diagnosis.

In the ICU investigated in the present study, professionals still confuse palliativeness with end-of-life care. Thus, the stigma that $\mathrm{PC}$ is synonymous with terminal care must be broken.

This fact may be explained through the way decisions are still exclusive to the medical team, for even though the outcomes depend on a multiprofessional team, with the graduate and undergraduate degrees found in most of the participants, standardization of practices is still lacking, there is insufficient communication, and knowledge on PC is not shared with all multiprofessional team members.

Thus, this study shows a gap in the standardization of practices, without, however, disregarding the specificities of patient care, justifying the need for building care protocols for $\mathrm{PC}$ patients.

\section{RESUMO}

Objetivo: Conhecer a percepção dos profissionais de saúde de uma Unidade de Terapia Intensiva acerca do cuidado paliativo. Método: Pesquisa descritiva, qualitativa do tipo Convergente Assistencial realizada em uma Unidade de Terapia Intensiva da região sul do Brasil. Utilizou-se de entrevista semiestruturada que investigou o entendimento e a compreensão sobre cuidado paliativo nesta unidade. Os dados foram organizados e analisados pela técnica do discurso do sujeito coletivo com auxílio do software Qualiquantisoft ${ }^{\circledR}$. Resultados: Participaram do estudo 37 profissionais (12 enfermeiros, 11 técnicos de enfermagem, cinco fisioterapeutas e nove médicos). As ideias centrais extraídas dos relatos: cuidado na fase terminal da vida sem medidas fúteis; cuidados de conforto; falta uniformizar a assistência e falta capacitação para a equipe. Conclusão: Os profissionais percebem o cuidado paliativo apropriado na fase terminal da vida, sem necessidade de medidas fúteis de tratamento e promotoras de conforto. No entanto, estão conscientes da falta de uniformização e da sua capacitação nesta matéria, o que os leva a conceber o paliativismo como cuidado de terminalidade, pelo que se recomendam medidas para romper com este estigma.

\section{DESCRITORES \\ Cuidados Paliativos; Unidades de Terapia Intensiva; Equipe de Enfermagem; Equipe de Assistência ao Paciente.}

\section{RESUMEN}

Objetivo: Conocer la percepción de los profesionales sanitarios de una Unidad de Cuidados Intensivos acerca del cuidado paliativo. Método: Investigación descriptiva, cualitativa del tipo Convergente Asistencial realizada en una Unidad de Cuidados Intensivos de la región sur de Brasil. Se empleó entrevista semiestructurada que investigó el entendimiento y la comprensión acerca del cuidado paliativo en esa unidad. Los datos fueron organizados y analizados por la técnica del discurso del sujeto colectivo con auxilio del software Qualiquantisoft ${ }^{\circledR}$. Resultados: Participaron en el estudio 37 profesionales (12 enfermeros, 11 técnicos de enfermería, cinco fisioterapeutas y nueve médicos). Las ideas centrales extraídas de los relatos: cuidado en la fase terminal de la vida sin medidas fútiles; cuidados de confort; ausencia de uniformización de la asistencia y de capacitación para el equipo. Conclusión: Los profesionales perciben el cuidado paliativo apropiado en la fase terminal de la vida, sin necesidad de medidas fútiles de tratamiento y promotoras de confort. Sin embargo, están enterados de la falta de uniformización y de su capacitación en esa materia, lo que lleva a concebir el paliativismo como cuidado de terminalidad, por lo que se recomiendan medidas para romper dicho estigma.

\section{DESCRIPTORES}

Cuidados Paliativos; Unidades de Cuidados Intensivos; Grupo de Enfermería; Grupo de Atención al Paciente.

\section{REFERENCES}

1. Hua M, Wunsch H. Integrating palliative care in the ICU. Curr Opin Crit Care. 2014;20(6): 673-80.

2. Nelson JE, Curtis JR, Mulkerin C, Campbell M, Lustbader DR, Mosenthal AC, et al. Choosing and using screening criteria for palliative care consultation in the icu: a report from the improving palliative care in the ICU (IPAL-ICU) Advisory Board. Crit Care Med. 2013; 41(10):2318-27 .

3. Pimenta CAM. Palliative care: a new specialty in profession of nursing? [editorial]. Acta Paul Enferm. 2010;23(3):ix.

4. Ferreira MAL, Pereira AMNA, Martins JCA, Barbieri-Figueiredo MC. Palliative care and nursing in dissertations and theses in Portugal: a bibliometric study. Rev Esc Enferm USP. 2016;50(2):313-19. DOI: http://dx.doi.org/10.1590/S0080-623420160000200019

5. Aslakson RA, Curtis JR, Nelson JE. The changing role of palliative care in the ICU. Crit Care Med. 2014;42(11):2418-28.

6. Academia Nacional de Cuidados Paliativos (ANCP). Manual de cuidados paliativos. $2^{\text {a }}$ ed. São Paulo: ANCP; 2012.

7. Edwards JD, Voigt LP, Nelson JE. Ten key points about ICU palliative care. Intensive Care Med. 2017;43(1):83-5. 
8. Silva CF, Souza DM, Pedreira LC, Santos MR, Faustino TN. Concepções da equipe multiprofissional sobre a implementação dos cuidados paliativos na unidade de terapia intensiva. Ciênc Saúde Coletiva. 2013;18(9):2597-604.

9. Trentini M, Paim L, Silva DMG. Pesquisa convergente assistencial: delineamento provocador de mudanças nas práticas de saúde. $3^{a}$ ed. Porto alegre: Moriá; 2014.

10. Brasil. Ministério da Saúde; Conselho Nacional de Saúde. Resolução n. 466, de 12 de dezembro de 2012. Dispõe sobre normas e diretrizes de pesquisas envolvendo seres humanos [Internet]. Brasília; 2012 [citado 2016 jan. 08]. Disponível em: http://conselho.saude.gov.br/ resolucoes/2012/Reso466.pdf

11. Lefèvre F, Lefèvre AMC. Pesquisa de representação social: um enfoque qualiquantitativo. Brasília: Líber Livro; 2012.

12. Fonseca AC, Mendes Junior WV, Fonseca MJM. Cuidados paliativos para idosos na unidade de terapia intensiva: revisão sistemática. Rev Bras Ter Intensiva. 2012;24(2):197-206.

13. Van Mechelen W, Aertgeerts B, De Ceulaer K, Thoonsen B, Vermandere M, Warmenhoven F, et al. Defining the palliative care patient: a systematic review. Palliat Med. 2013;27(3):197-208.

14. Frontera JA, Curtis JR, Nelson JE, Campbell M, Gabriel M, Mosenthal AC, et al. Integrating palliative care into the care of neurocritically ill patients: a report from the improving palliative care in the ICU Project Advisory Board and the Center to Advance Palliative Care. Crit Care Med. 2015;43(9):1964-77.

15. Bausewein C, Higginson IJ. Challenges in defining 'palliative care' for the purposes of clinical trials. Curr Opin Support Palliat Care. 2012;6(4):471-82.

16. Saft HL, Richman PS, Berman AR, Mularski RA, Kvale PA, Ray DE, et al. Impact of critical care medicine training programs' palliative care education and bedside tools on ICU use at the end of life. J Grad Med Educ. 2014;6(1):44-9.

17. Izumi S, Nagae H, Sakurai C, Imamura E. Defining end-of-life care from perspectives of nursing ethics. Nurs Ethics. 2012;19(5):608-18.

18. Hansen L, Press N, Rosenkranz SJ, Baggs JG, Kendall J, Kerber A, et al. Life-sustaining treatment decisions in the ICU for patients with ESLD: a prospective investigation. Res Nurs Health. 2012;35(5):518-32.

19. Wiedermann C J, Lehner GF, Joannidis M. From persistence to palliation: limiting active treatment in the ICU. Curr Opin Crit Care. 2012;18(6):693-9.

20. Jensen $\mathrm{HI}$, Ammentorp J, Ording H. Guidelines for withholding and withdrawing therapy in the ICU: impact on decision-making process and interdisciplinary collaboration. Heart Lung Vessel. 2013;5(3):158-67.

21. Araújo MMT, Silva MJP. O conhecimento de estratégias de comunicação no atendimento à dimensão emocional em cuidados paliativos. Texto Contexto Enferm. 2012;21(1):121-9.

22. Grant M. Resolving communication challenges in the intensive care unit. AACN Adv Crit Care. 2015;26(2):123-30.

23. Wessman BT, Sona C, Schallom M. Improving caregivers' perceptions regarding patient goals of care/end-of-life issues for the multidisciplinary critical care team. J Intensive Care Med. 2017;32(1):68-76.

24. Cardoso DH, Muniz RM, Schwartz E, Arrieira ICO. Hospice care in a hospital setting: the experience of a multidisciplinary team. Texto Contexto Enferm. 2013;22(4):1134-41.

25. Vargas MAO, Vivan J, Vieira RW, Mancia JR, Ramos FRS, Ferrazzo S, et al. Redefining palliative care at a specialized care center: a possible reality? Texto Contexto Enferm. 2013; 22(3):637-45. 